\title{
PENYELESAIAN MASALAH SYARAT BATAS PERSAMAAN DIFERENSIAL BIASA DALAM SCILAB DENGAN MENGGUNAKAN BVODE
}

\author{
A. D. GARNADI ${ }^{1}$, F. AYATULLAH ${ }^{1}$, D. EKASTRYA ${ }^{1}$, S. NURDIATI ${ }^{1}$, \\ M.T. JULIANTO ${ }^{1}$, W. ERLIANA ${ }^{1}$
}

\begin{abstract}
Abstrak
Diuraikan penggunaan rutin bvode di lingkungan SCILAB untuk menyelesaikan masalah syarat batas sistem persamaan diferensial biasa.Tujuannya ialah agar pengguna dapat mempergunakan bvode setelah membaca uraian penggunaannya.Penggunaan rutin digambarkan dengan tiga contoh yang memperlihatkan kegunaannya.
\end{abstract}

\section{PENDAHULUAN}

Persamaan Diferensial Biasa (PDB) sering muncul sebagai model permasalahan dalam berbagai bidang ilmu pengetahuan.Pencarian solusi PDB diperlukan untuk memperoleh interpretasi dari model permasalahan semula.Solusi analitik dari suatu PDB tidak selalu mudah diperoleh. Pada umumnya, untuk mencari salah satu solusi yang dikehendaki dari suatu sistem PDB, diperlukan suatu nilai awal yang memenuhi sistem PDB tersebut pada suatu titik $\quad \therefore$ Permasalahan seperti ini dikenal dengan nama Masalah Nilai Awal (MNA), yang secara ringkas dapat dinyatakan oleh:

$$
\begin{aligned}
y^{n} & =f\left(x, y, y^{\prime}, y^{\prime \prime}, \ldots, y^{n-1}\right) \\
y(a) & =b
\end{aligned}
$$

Ada kalanya solusi yang sangat spesifik ingin didapatkan dari suatu sistem PDB dengan cara menentukan nilai-nilai awal pada lebih dari satu titik $x$. Permasalahan seperti ini dikenal dengan nama Masalah Syarat Batas (MSB), yang dapat dinyatakan oleh :

$$
\begin{aligned}
y^{n} & =f\left(x, y, y^{\prime}, y^{\prime \prime}, \ldots, y^{n-1}\right) \\
y\left(a_{1}\right) & =b_{1} \\
y\left(a_{2}\right) & =b_{2}
\end{aligned}
$$

Rutin numerik yang mampu menyelesaikan MNA telah banyak dikembangkan, namun sedikit yang mampu menyelesaikan MSB.Sebuah rutin untuk menyelesaikan MSB berdasarkan metode kolokasi disediakan

\footnotetext{
${ }^{1}$ Departemen Matematika, Fakultas IImu Pengetahuan Alam, Jalan Meranti Kampus IPB Dramaga Bogor, 16680.
} 
dalam lingkungan Scilab, rutin ini bernama bvode.Metode kolokasi juga digunakan dalam lingkungan MATLAB untuk rutin bvp4c yang disediakannya.

Tulisan ini merupakan sebuah tutorial yang memberikan penuntun bagaimana memformulasikan masalah (menyusun perintah), mendapatkan solusi numerik, dan menggambarkan solusi secara grafis dari MSB dengan menggunakan rutin bvode. Tulisan ini juga merupakan studi pendahuluan numerik atas ketersediaan lingkungan pemecah masalah numerik (numerical problem solving environment\{PSE\})yang bersifat open-source sebagai alternatif dari PSE komersial populer MATLAB yang menawarkan rutin bvp4c untuk memecahkan MSB.

Salah satu tujuan tulisan ini bersifat pedagogis yang menguraikan secara sederhana bagaimana memperoleh solusi numerik MSB sebuah PDB.Dengan demikian, seorang pemula dapat mempergunakan bvode untuk menyelesaikan MSB yang dihadapinya tanpa kesulitan.Selain itu, contoh yang diberikan muncul dari masalah perkuliahan yang biasanya ditemui di tahun ketiga atau keempat di perguruan tinggi.Selain itu, tulisan ini bertujuan untuk menyediakan dokumentasi tertulis berbahasa Indonesia.Tujuan lainnya ialah memberikan teladan penggunaan Open Source dilingkungan komputasi matematika di Indonesia, yang secara tidak langsung memberi dukungan pada proyek nasional IGOS (Indonesia Goes Open Source).

Tulisan ini disusun dengan urutan sebagai berikut.Pertama diuraikan deskripsi dari bvode.Kemudian diperlihatkan penggunaannya untuk tiga buah contoh diluar contoh yang diberikan dalam lingkungan Scilab tentang bagaimana mempergunakan bvode untuk menyelesaikan sebuah MSB.Kemudian diakhiri oleh kesimpulan serta kemungkinan pekerjaan lanjutan.

\section{DESKRIPSI bvode}

Rutin bvode yang tersedia dalam PSE Scilab, merupakan perangkat simulasi untuk menyelesaikan MSB.Rutin bvode pada dasarnya mempergunakan pustaka COLNEW yang merupakan perbaikan dari rutin program COLSYS ([1], [2]) yang ditulis mempergunakan FORTRAN dan berlandaskan metode kolokasi.Tidak seperti solver PDB pada umumnya, bvode tidak mengharuskan pengguna mengubah persamaan diferensial orde tinggi menjadi sistem persamaan diferensial orde satu. Selain itu, dimungkinkan diberikannya sejumlah syarat di sejumlah titik .

Bentuk MSB yang diasumsikan oleh bvode ialah: 


$$
\begin{gathered}
\frac{d^{m_{\mathrm{i}}} y_{i}}{d x^{m_{\mathrm{i}}}}=f_{i}\left(x, y(x), \frac{d y}{d x}, \ldots, \frac{d^{m_{\mathrm{i}}-1} y_{i}}{d x^{m_{\mathrm{i}}-1}}\right), \quad 1 \leq i \leq n_{c}, \\
g_{j}\left(\zeta_{j} y\left(\zeta_{j}\right), \ldots, \frac{d^{m_{*}}}{d x^{m_{*}}}\left(\zeta_{j}\right)\right)=0, \quad j=1, .
\end{gathered}
$$

Dengan merupakan posisi dimana syarat batas berlaju dan $a_{L} \leq \zeta_{j}$. Agar notasi tidak menyulitkan, tuliskan

$$
\begin{aligned}
& m_{*}=m_{1}+m_{2}+\cdots+m_{n_{e^{\prime}}} \\
& z(y)=\left[y, \frac{d y}{d x}, \ldots, \frac{d^{m_{*}} y}{d x^{m_{*}}}\right] .
\end{aligned}
$$

Dengan demikian, bentuk umum MSB yang diasumsikan oleh bvode ialah

$$
\begin{gathered}
\frac{d^{m_{i}} y_{i}}{d x^{m_{i}}}=f_{i}(x, z(y(x))), \quad 1 \leq i \leq n_{c}, \quad a_{L} \leq \zeta_{j} \leq a_{R}, \\
g_{j}\left(\zeta_{j} z\left(y\left(\zeta_{j}\right)\right)\right)=0, \quad j=1, .
\end{gathered}
$$

Rutin bvode memiliki kemampuan untuk menyelesaikan MSB yang linear maupun non-linear. Karena itu rutin ini mengharuskan pengguna menyusun sendiri matriks Jacobian dari PDB yang hendak diselesaikan, maka untuk beberapa masalah, tingkat kerumitan yang paling besar akan terasa pada penyusunan matriks Jacobian ini.

Seperti halnya fungsi lain pada SCILAB, rutin bvode memiliki tata cara pemanggilan sebagai berikut ini

$$
\begin{aligned}
& \text { [ z ] = bvode(points,ncomp,m,aleft,aright,zeta,ipar,... } \\
& \text { Itol,tol,fixpnt,fsub,dfsub,gsub,dgsub,guess); }
\end{aligned}
$$

denganz merupakan vektor baris yang berisi solusi numerik dari MSB yang ingin diselesaikan. Komponen $z(i,:)$ merepresentasikan turunan ke- $(i-$ 1) dari solusi pada selang domain. Sebagai contoh, $z(1,:)$ menyatakan $y$, $z(2,:)$ menyatakan $y^{\prime}$, dan seterusnya hingga $z\left(m^{*},:\right)$ menyatakan $y^{\left(m^{*}-1\right)}$.

Lima argumen terakhir yang diperlukan bvodeberbentuk fungsi yang harus didefinisikan sendiri oleh pengguna, sedangkan argumen lainnya merupakan informasi yang diperlukan bvode untuk dapat mencari solusi numerik berkaitan dengan MSB yang ingin diselesaikan.Berikut adalah penjelasan kegunaan masing-masing parameter yang digunakan oleh bvode.

Z Solusi dari PDB yang dievaluasi atas mesh yang diberikan oleh points.

Points : Array yang menyimpan titik di selang domain dimana MSB akan dicari solusinya. 


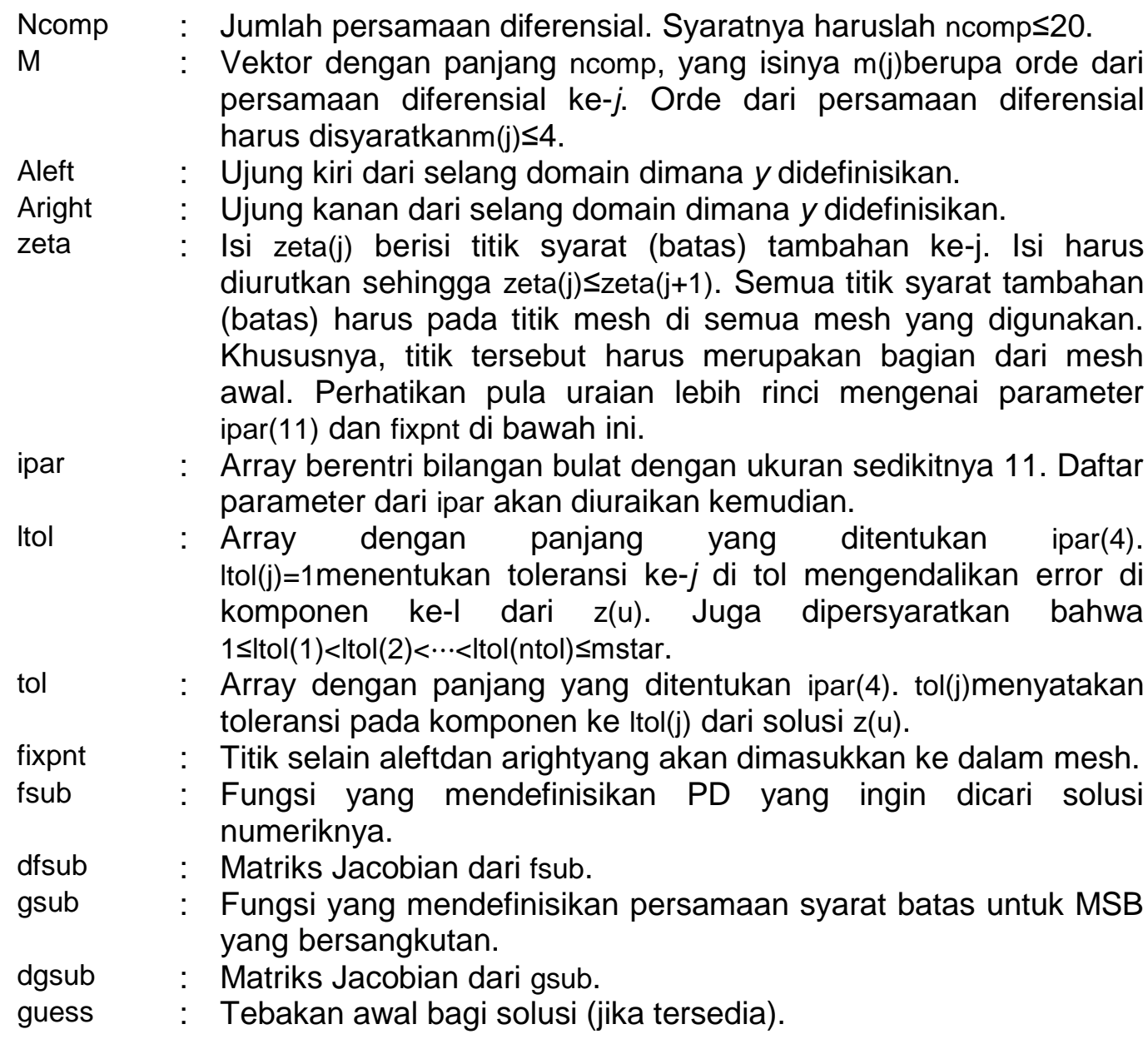

Dari kelimabelas parameter di atas, argumen ipar adalah argumen yang paling panjang.Argumen ini memiliki 11 komponen yang secara keseluruhan memberi kesempatan pengguna untuk mengatur setting pada metode numerik yang digunakan bvode.Sebagian komponen dari parameter ipar berhubungan langsung dengan beberapa argumen bvode pada daftar parameter di atas. Sebagian besar dari komponen-komponen tersebut memiliki nilai default nol. Karena jumlah komponennya yang terbilang cukup banyak, ada baiknya jika dibuat variabel berdimensi $1 \times 11$ yang berisi nilai nol (default) sebelum mengisi komponen-komponen yang tidak bernilai default, yaitu

ipar $=\operatorname{zeros}(1,11)$;

Isikan masing-masing komponen parameter ipar berdasarkan keterangan yang didaftarkan di bawah ini:

ipar(1) $\quad: \quad=0$ jika MSB linear dan = 1 jika MSB non-linear.

ipar(2) : Banyaknya titik kolokasi per subinterval $(=k)$ dimana orde maksimum $P D \leq k \leq 7$. Jika ipar(2)=0maka secara default $k=$ $\max (\max m(i)+1,5-\max m(i))$. 


\begin{abstract}
ipar(3) : Banyaknya subinterval pada mesh awal $(=n)$. Jika ipar(3) = 0 maka secara default $n=5$.

ipar(4) : Banyaknya komponen solusi beserta turunannya yang diberi toleransi (=ntol), dengan aturan $0 \leq n$ tol $\leq m^{*}$.

ipar(5) : Nilai yang menentukan banyaknya subinterval maksimum (nmax) pada selang domain. Pilihlah ipar(5)berdasarkan rumus berikut: ipar(5) $\geq i p a r(5) \cdot$ nsizef di mana nsizef $=4+3 m^{*}+(5+k d) \cdot k d m+\left(2 m^{*}-\right.$ nrec). $2 m^{*}$ dengan nrec adalah banyaknya syarat batas pada ujung kanan selang domain ipar(5) diperuntukkan evaluasi pada titik-titik selang real.

ipar(6) : Nilai yang menentukan banyaknya subinterval maksimum nmax pada selang domain. Pilihlah ipar(6) berdasarkan rumus berikut: $\operatorname{ipar}(6) \geq n m a x$.nsizei di mana nsizei $=3+\mathrm{kdm}$ dengan $\mathrm{kdm}=\mathrm{kd}+\mathrm{m}^{*} ; \mathrm{kd}=$ k.ncomp; ipar(6) diperuntukkan evaluasi pada titik-titik integer.

ipar(7) : Kontrol output berikan nilai berikut: $=-1$ untuk printout diagnostik penuh $=0$ untuk printout sederhana. $=1$ tanpa printout.

$\operatorname{ipar}(8) \quad: \quad=0$ untuk mesh awal seragam.

ipar(9) $\quad:=0$ jika tidak tersedia tebakan awal bagi solusi. = 1 jika tebakan awal tersedia pada fungsiguess.

ipar(10) $\quad=0$ jika masalah bersifat reguler. = 1 jika iterasi nonlinear tidak bergantung pada kekonvergenan dari iterasi sebelumnya (hanya digunakan jika ipar(1)=1). = 2 jika proses ingin dihentikan setelah (a)terjadi dua kali nonkonvergen berturut-turut, atau (b)pendekatan galat didapatkan untuk pertama kalinya.

ipar(11) : Banyaknya titik selain ujung-ujung selang domain yang akan dimasukkan ke dalam mesh (dimensi dari argumen fixpnt).
\end{abstract}

\title{
CONTOH
}

Pada bagian ini akan dibahas tiga contoh bagaimana menyelesaikan MSB dengan mempergunakan bvode. Pada bagian ini juga akan ditunjukkan bagaimana cara menggambar masing-masing komponen solusi numerik yang didapat dari bvode.

Contoh 1.Dalam contoh ini diberikan ilustrasi bagaimana mencari solusi numerik dari MSB yang melibatkan parameter yang tidak diketahui. Permasalahannya ialah menghitung nilai eigen dari persamaan Mathieu berikut ini,

$y^{t r}+(\lambda-2 q \cos (2 x)) y=0$

pada selang , dengan syarat batas $\quad y^{\prime}\left(0, \quad y^{\prime}(\pi\right.$ untuk

Solusi dinormalisasi dengan cara menetapkan solusi memenuhi $\quad y(\mathrm{o}$. Permasalahan sesungguhnya ialah mencari nilai yang memenuhi syarat batas $y^{\prime}(\pi$. Nilai tebakan awal bagi menjadi keharusan dalam 


\section{A.D. GARNADI, F. AYATULLAH, D. EKASTRYA, S. NURDIATI,} M. T. JULIANTO, W. ERLIANA

menyelesaikan masalah ini.MSB di atas diimplementasikan dalam SCILAB sebagai berikut ini.Persamaan diferensialnya didefinisikan dengan skrip berikut.

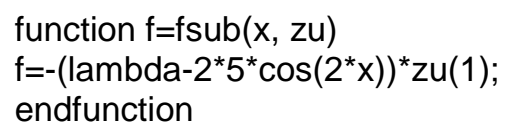

Untuk persamaan di atas, diperlukan matriks Jacobian yang ditulis dengan skrip seperti berikut ini.



Sementara syarat batasnya diberikan oleh:

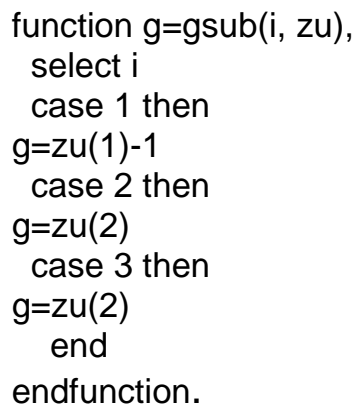

Untuk syarat batas tersebut di atas, diperlukan matriks Jacobian, yaitu

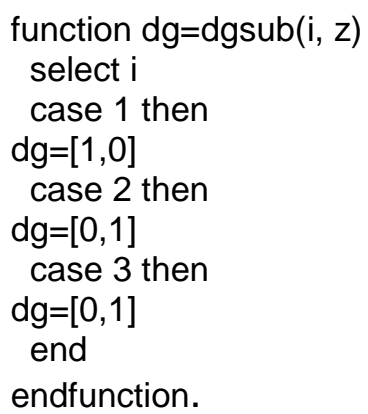

Berikut sejumlah parameter yang diperlukan, yaitu

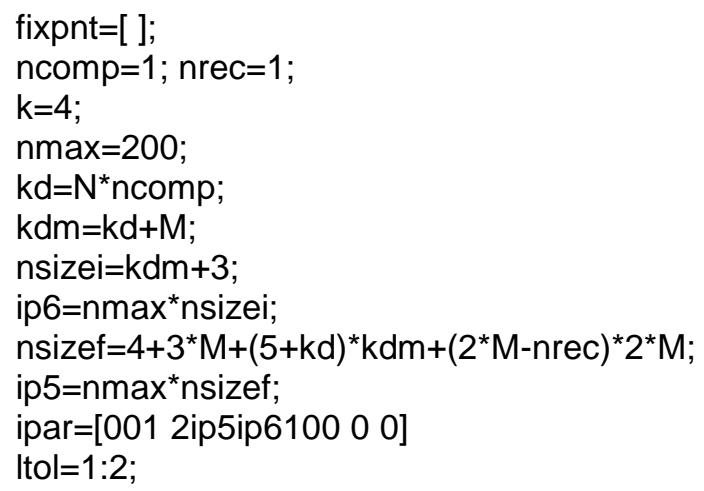


tol=[1.e-5,1.e-5];

Karena tebakan awal bagi solusi $y$ tidak tersedia maka fungsi guess didefinisikan seperti di bawah ini.

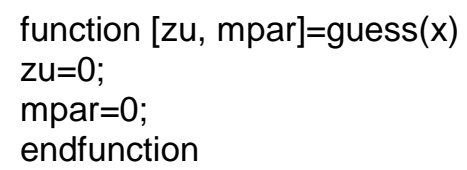

Jika tebakan awal bagi nilai eigen dipilih $=15$, maka untuk menyelesaikan MSB pada persamaan (7) sekaligus mendapatkan nilai pendekatan untuk dapat dilakukan dengan menambahkan loop seperti pada listing berikut,

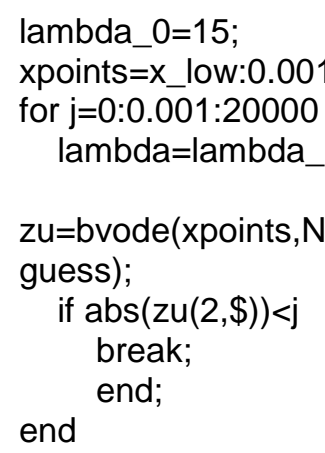

Untuk melihat gambar grafik solusi numerik untuk $y(x)$ yang dihasilkan bvode dan untuk mengetahui nilai yang didapat dari loop di atas, perintah berikut dengan cepat akan menampilkan keduanya:

lambda

plot2d(xpoints,zu(1,:));

Dari hasil perhitungan yang dilakukan oleh bvode beserta loop di atas, didapat nilai pendekatan $=16.058$ dan gambar grafik solusi $y(x)$ seperti yang terlihat pada Gambar 1. Perhitungan di atas mempergunakan mesh dengan lebar kisi $\Delta x=0.001$ yang seragam untuk selang $[0, \pi]$. 


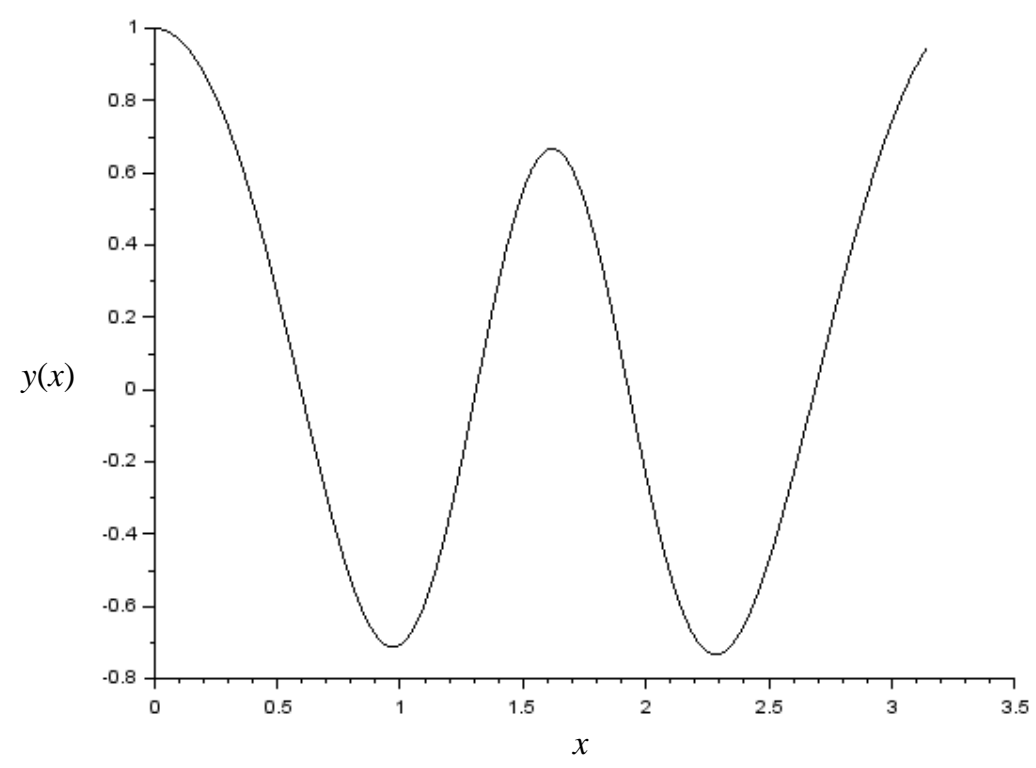

Gambar 1.Fungsi eigen dari persamaan Mathieu terkait dengan nilai eigen yang digunakan dalam artikel

Contoh 2.Pada contoh berikut diberikan sebuah MSB yang berasal dari Kontrol Optimal.Biasanya, syarat cukup untuk kontrol optimal berupa MSB, yang biasanya lebih mudah menyelesaikannya untuk banyak masalah sederhana.

$y^{\prime}=y^{2}+v$

Perhatikan masalah sistem terkontrol

dan kita inginkan kontrol $v$ mengendalikan lintasan dari 2 pada saat $t=0$ ke -1 pada saat $t=10$. Dengan demikian, kita inginkan $v$ meminimumkan ongkos kuadratik berikut

$$
l(y, v)=\int_{0}^{10}\left(y^{2}+10 v^{2}\right) d t .
$$

Fungsi ongkos ini menyebabkan variabel keadaan $y$ dan variabel kontrol $v$ terpenalisasi, sehingga menyebabkan variabel keadaan dan kontrol menjadi kecil.

Syarat cukup dapat diperoleh dengan mendefinisikan fungsi Hamiltonian

$$
H=\left(y^{2}+10 v^{2}\right)+\lambda\left(y^{2}+v\right)
$$

dan kita tuliskan masalah syarat batas persamaan diferensial aljabar

$y^{\prime}=\frac{\partial H}{\partial \lambda^{x}}$ 
$\lambda^{\prime}=\frac{\partial H}{\partial y^{\prime}}$

$0=\frac{\partial H}{\partial v^{s}}$

$y(0)=2, y(10)=1$,

Bila $v$ dieliminasi, akan diperoleh MSB

$y^{\prime}=y^{2}+v$,

$\lambda^{\prime}=-2 y-2 \lambda y$,

$0=20 v+\lambda$,

$y(0)=2, y(10)=1$,

MSB di atas diimplementasikan dalam SCILAB sebagai berikut ini.Persamaan diferensialnya didefinisikan dengan skrip berikut.

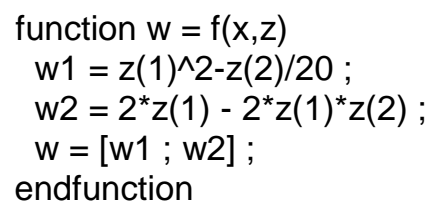

Untuk persamaan di atas, diperlukan matriks Jacobian yang ditulis dengan skrip seperti berikut ini.

function $w=d f(x, z)$

$w=\left[2^{\star} z(1),-1 / 20 ;-2-2^{\star} z(2),-2^{\star} z(1)\right]$;

endfunction

Sementara syarat batasnya diberikan oleh:

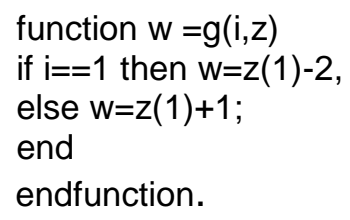

Untuk syarat batas tersebut di atas, diperlukan matriks Jacobian, yaitu function $w=d g(i, z)$ $\mathrm{w}=[10]$; endfunction.

MSB di atas, diselesaikan di atas selang $[0,10]$ dengan lebar kisi $\Delta t$ $=0.1$ yang seragam, berikut sejumlah parameter yang diperlukan, yaitu $\mathrm{tt}=0: 0.1: 10$; ncomp $=2 ;$ nrec $=1$; $\mathrm{m}=[11] ; \mathrm{k}=4$; nmax $=200$; mstar=2; 


\section{A.D. GARNADI, F. AYATULLAH, D. EKASTRYA, S. NURDIATI,}

M. T. JULIANTO, W. ERLIANA

$k d=k^{*} n c o m p ;$

$\mathrm{kdm}=\mathrm{kd}+\mathrm{mstar}$;

nsizei $=\mathrm{kdm}+3$;

ip6=nmax ${ }^{*}$ nsizei;

nsizef $=4+3^{*} m s t a r+(5+k d){ }^{*} k d m+\left(2^{*} m s t a r-n r e c\right)^{*} 2^{*} m s t a r ;$

ip5=nmax ${ }^{*}$ nsizef;

zeta $=\left[\begin{array}{ll}0 & 10\end{array}\right]$

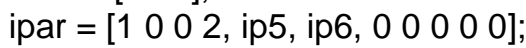

er $=1.0 \mathrm{~d}-3$;

Itol=1:2;

tol $=[\mathrm{er}, \mathrm{er}]$;

dan kita berikan fungsi tebakan awal, yaitu

function $\mathrm{w}=\mathrm{gs}(\mathrm{x})$

$w=[0,0 ; 0,0]$

endfunction.

Kemudian untuk memperoleh solusi numerik MSB, diberikan dalam skrip SCILAB berikut

$\mathrm{zz}=$ bvode $(\mathrm{tt}, 2, \mathrm{~m}, 0,10, \mathrm{zeta}, \mathrm{ipar}, \mathrm{ltol}, \mathrm{tol}, 0, \mathrm{f}, \mathrm{df}, \mathrm{g}, \mathrm{dg}, \mathrm{gs}) ;$

control $=-(1 / 20)^{\star} z z(2,:)$;

Solusi numerik yang diperoleh, ditampilkan oleh Scilab dengan memberikan skrip berikut ini

$\operatorname{plot} 2 \mathrm{~d}(\mathrm{tt}, \mathrm{zz}(1,:))$;

plot2d(tt,control);

plot2d(tt,control,style=-1);

yang tampilan grafisnya diperlihatkan pada Gambar 2.

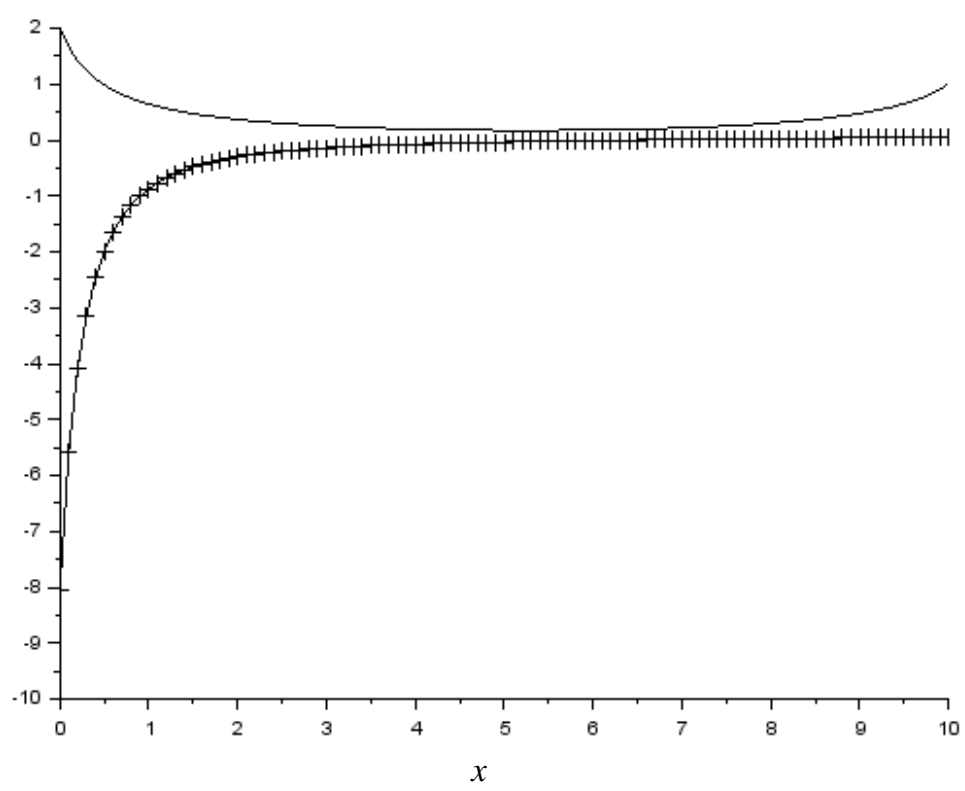

Gambar 2. Optimal $y$ (garis) dan kontrol $v$ (garis- $x$ ) untuk contoh 2. 
Contoh 3.Pada contoh berikut diberikan sebuah MSB yang berasal dari formula kredibilitas yang memungkinkan aktuaris untuk menyeimbangkan dua hal, yaitu keakuratan dan kelinearan [9]. Berikut merupakan MSB untuk kasus di mana sebaran marginal ( ) dari besarnya klaim( ) ialah tak nol pada suatu interval terbatas , lihat Young [10].

$\frac{h}{f(x)}\left[f(x) d^{\prime \prime}(x)\right]^{\prime \prime}+d(x)=\mu(x)$,

dengan

$d^{\prime \prime}(a)=d^{\prime \prime}(b)=d^{\prime \prime \prime}(a)=d^{\prime \prime \prime}(b)=0$.

Pada contoh ini, misalkan $f(x$ pada interval,$\quad h=0$, dan

$\mu(x)=\frac{2}{(x+2) \ln 1.5}-2+\frac{2}{(x+2)} \int_{1}^{0.5 x+1} \frac{3-2 \theta}{\ln 1.5-\ln \theta} d \theta$.

Misalkan pula

$v(x)=\int_{1}^{0.5 x+1} \frac{3-2 \theta}{\ln 1.5-\ln \theta} d \theta$,

sehingga

$v^{\prime}(x)=\frac{1-x}{2[\ln 1.5-\ln (0.5 x+1)]}$.

Dengan demikian, persamaan (10) menjadi

$$
\begin{aligned}
0.0025 d^{\prime \prime \prime}(x)+d(x) & =\frac{2}{(x+2) \ln 1.5}-2+\frac{2}{(x+2)} v(x) \\
d^{\prime \prime \prime}(x) & =\frac{1}{0.0025}\left[\frac{2}{(x+2) \ln 1.5}-2+\frac{2}{(x+2)} v(x)-d(x)\right] .
\end{aligned}
$$

Jadi, MSB untuk kasus tersebut ialah

$$
\begin{aligned}
& v^{\prime}(x)=\frac{1-x}{2[\ln 1.5-\ln (0.5 x+1)]^{\prime}} \\
& d^{\prime \prime \prime \prime}(x)=\frac{1}{0.0025}\left[\frac{2}{(x+2) \ln 1.5}-2+\frac{2}{(x+2)} v(x)-d(x)\right],
\end{aligned}
$$

dengan

$v(0)=d^{\prime \prime}(0)=d^{\prime \prime}(1)=d^{\prime \prime \prime}(0)=d^{\prime \prime \prime}(1)=0$.

MSB di atas diimplementasikan dalam SCILAB sebagai berikut.Persamaan diferensialnya didefinisikan dengan skrip berikut.

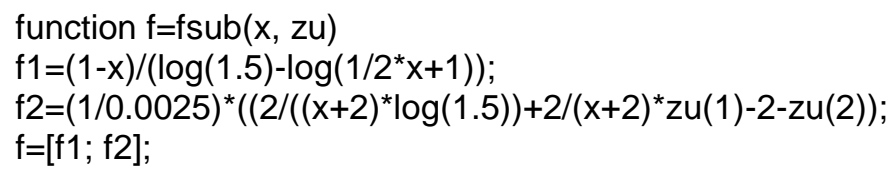




\section{A.D. GARNADI, F. AYATULLAH, D. EKASTRYA, S. NURDIATI,} M. T. JULIANTO, W. ERLIANA

endfunction

Untuk persamaan di atas, diperlukan matriks Jacobian yang ditulis dengan skrip seperti berikut ini.

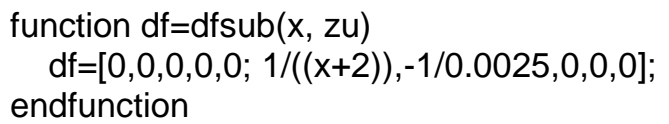

Sementara syarat batasnya diberikan oleh:

function $\mathrm{g}=\mathrm{gsub}(\mathrm{i}, \mathrm{zu})$,

select i

case 1 then

$\mathrm{g}=\mathrm{zu}(1)$

case 2 then

$\mathrm{g}=\mathrm{zu}(4)$

case 3 then

$\mathrm{g}=\mathrm{zu}(5)$

case 4 then

$\mathrm{g}=\mathrm{zu}(4)$

case 5 then

$g=z u(5)$

end

endfunction

Untuk syarat batas tersebut, diperlukan matriks Jacobian, yaitu

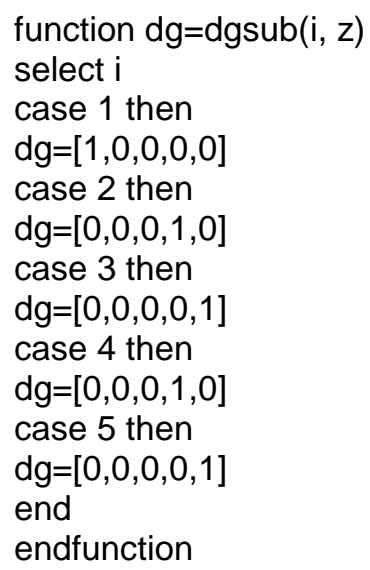

MSB di atas, diselesaikan di atas selang $[0,1]$ dengan lebar kisi $\Delta t=$ 0.01 yang seragam, berikut sejumlah parameter yang diperlukan, yaitu

$\mathrm{N}=2$;

$\mathrm{m}=[14]$

$\mathrm{M}=\operatorname{sum}(\mathrm{m})$;

x_low $=0 ; x \_u p=1$;

fixpnt=[ ];

xpoints=x_low:0.01:x_up;

ncomp $=2 ;$ nrec $=2$;

$\mathrm{m}=[14] ; \mathrm{k}=4$;

nmax=200; 
$\mathrm{kd}=\mathrm{N}^{*}$ ncomp;

$\mathrm{kdm}=\mathrm{kd}+\mathrm{M}$;

nsizei $=\mathrm{kdm}+3$;

ip6=nmax ${ }^{*}$ nsizei;

nsizef $=4+3^{*} M+(5+k d)^{*} k d m+\left(2^{*} M-n r e c\right)^{*} 2^{*} M$;

ip5=nmax*nsizef;

ipar $=[0,0,10,5$, ip5,ip6, $-1,0,0,0,0]$

Itol $=1: 5$;

tol=[1.e-11,1.e-11,1.e-11,1.e-11,1.e-11,1.e-11]

dan kita berikan fungsi tebakan awal, yaitu

function $\mathrm{w}=$ guess $(\mathrm{x})$

$w=[0,0 ; 0,0]$;

endfunction

Kemudian untuk memperoleh solusi numerik MSB, diberikan dalam skrip SCILAB berikut ess)

zu=bvode(xpoints,N,m,x_low,x_up,zeta,ipar,Itol,tol,fixpnt,fsub,dfsub,gsub,dgsub,gu

Solusi numerik yang diperoleh, ditampilkan oleh Scilab dengan memberikan skrip berikut ini

plot(xpoints,zu(1,:)).

Tampilan grafisnya diperlihatkan pada Gambar 3.

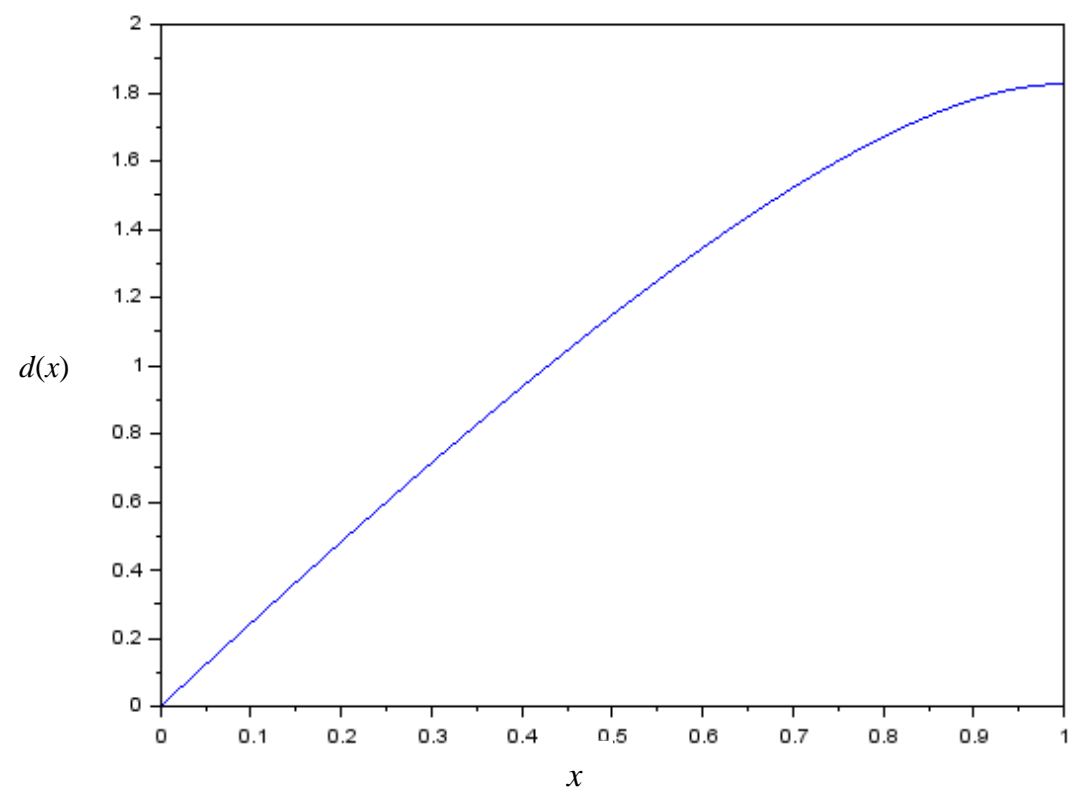

Gambar 3. Solusi optimum (d)dengan $h=0.0025$. 


\section{SIMPULAN}

Masalah syarat batas sering muncul sebagai model dari berbagai bidang ilmu.Karena solusi analitik MSB tidak selalu tersedia, metode numerik menjadi salah satu cara untuk memperoleh solusinya. Selain itu, dengan tersedianya rutin yang memudahkan pengguna untuk menyelesaikan MSB secara numerik, dimungkinkan melakukan simulasi secara berulang untuk menguji berbagai skenario pemodelan.Tulisan ini mendemonstrasikan rutin simulasi MSB dalam lingkungan problem solving environment SCILAB yang bersifat open source. Perlu kiranya pengujian lebih lanjut atas rutin ini, seperti halnya dilakukan oleh [7] yang menguji rutin simulasi MSB di lingkungan komersial MATLAB. Pengujian beragam MSB dari berbagai bidang ilmu sebagaimana diberikan oleh [2], dapat diujikan di lingkungan SCILAB untuk bahasan lanjutan.

\section{UCAPAN TERIMA KASIH}

Penelitian ini dibiayai secara parsial oleh Hibah Penelitian PUPTIPB melalui nomor kontrak : 083/SP2H/PL/Dit.Litabmas/II/2015. Terima kasih juga kepada DAAD atas bantuan literatur ilmiah berdasar kontrak no A/97/42703.

\section{DAFTAR PUSTAKA}

[1] Ascher U, Christiansen J, Russel RD. 1981. Collocation Software for BoundaryValue ODEs.ACM Transactions on Mathematical Software. 7(2).

[2] Ascher U, Mattheij RM, Russel RD, Numerical Solution of Boundary Value Problem.New Jersey: Prentice-Hall, Englewood Cliffs.

[3] Campbell SL. Chancelier JP, Nikoukhah R. 2005.Modeling and Simulation in Scilab/Scicos. Springer.

[4] Higham DJ, Higham NJ. 2000.MATLAB Guide. SIAM.

[5] Kierzenka J, Shampine L. 2001. A BVP solver on residual control and the Matlab PSE.ACM Transactions on Mathematical Software.27(3): 299-316.

[6] Moler CB. 2004.Numerical Computing with MATLAB. SIAM.

[7] Shampine L, Kierzenka J, Reichelt M. Solving Boundary Value Problems for Ordinary Differential Equations in Matlab with bvp4c, [http://www.mathworks.com/support/solutions/files/s8314/bvp_paper.pdf].

[8] Layar bantuan SCILAB untuk rutin bvode.

[9] Kaas R,Goovaerts M, Dhaene J, Denuit M. 2009.Credibility theory. Modern Actuarial Risk Theory: Using R.203-229.

[10] Young VR. 1997. Credibility using a loss function from spline theory. Scandinavian Actuarial Journal. 1997(2): 160-185. 


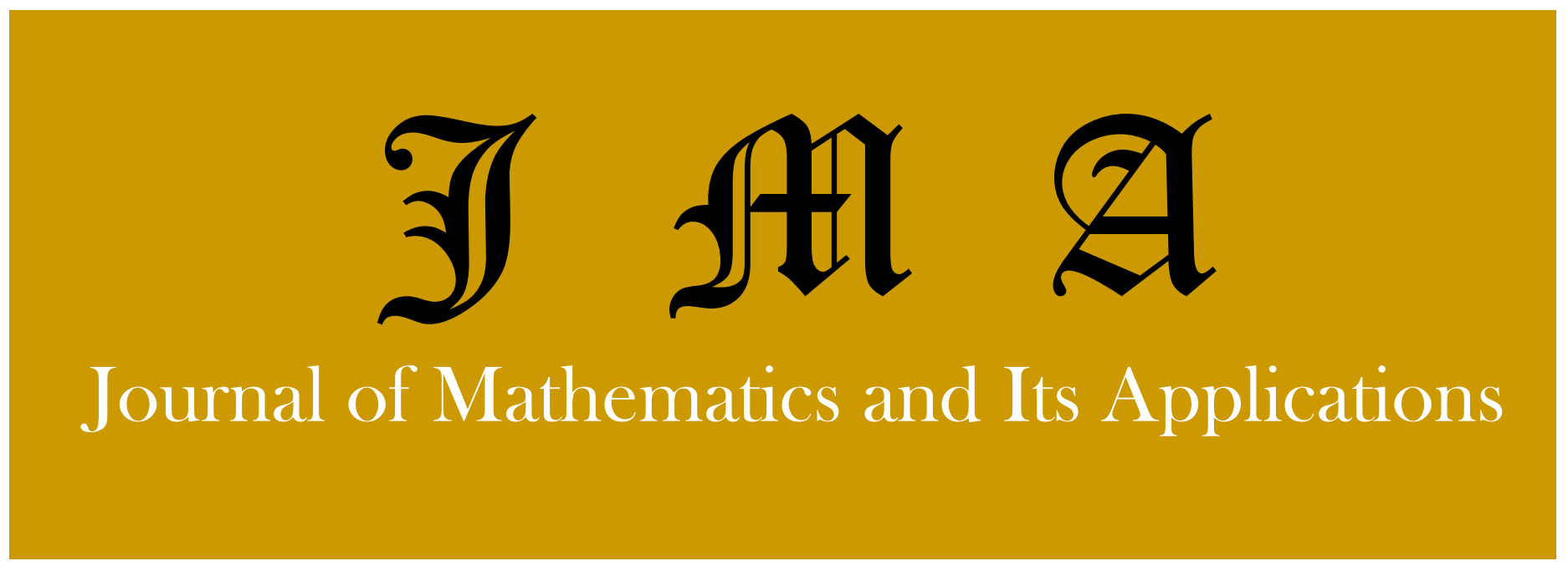

Volume 14, No. 1 July 2015

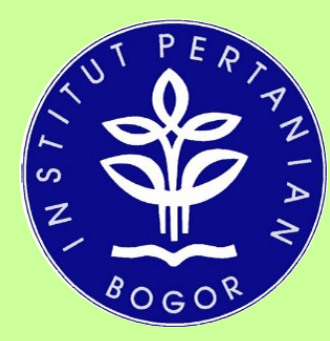

Department of Mathematics FMIPA - Institut Pertanian Bogor

JIn. Meranti, Kampus IPB Dramaga - Bogor

Phone/Fax: (0251) 8625276

E-mail: math@ipb.ac.id jma.mathipb@gmail.com
Metode Steepest Descent dengan Ukuran Langkah Baru untuk Pengoptimuman Nirkendala

D. Wungguli, B. P. Silalahi, dan S. Guritman

Model Pendugaan Kerugian Akibat Bencana Letusan Gunung Api di Sektor Pertanian

L. D. Asih, H. Sumarno, dan P. Sianturi

Kajian Teoritik Kelas Kunci Lemah pada Kriptosistem Idea Berdasarkan Faktor Linear dan Kriptanalisis Diferensial

G. Taufik, S. Guritman, dan B. P. Silalahi

Dekoding Sindrom Kode Gilbert-Varshamov Biner Berjarak Minimum Rendah

A. Saepulrohman, S. Guritman, dan B. P. Silalahi

Penyelesaian Masalah Syarat Batas Persamaan Diferensial Biasa dalam Scilab dengan Menggunakan BVODE

A. D. Garnadi, F. Ayatullah, D. Ekastrya, S. Nurdiati, M. T. Julianto, dan W. Erliana

Perilaku Dinamis Model Mangsa-Pemangsa Tipe Gause yang Diperumum dengan Waktu Tunda Pemanenan Konstan

Hasannudin, A. Kusnanto, dan Jaharuddin 


\title{
$\mathfrak{I} \mathfrak{A} \mathfrak{A}$
}

Journal of Mathematics and Its Applications

\author{
Editor In Chief \\ I Wayan Mangku, Institut Pertanian Bogor
}

\section{Executive Editor}

Windiani Erliana, Institut Pertanian Bogor

Managing Editor

M. Tito Julianto, Institut Pertanian Bogor

Editorial Boards

Alhadi Bustamam

Amril Aman

Fahren Bukhari

I Gusti Putu Purnaba

Kiki Arianti Sugeng

Paian Sianturi

Saib Suwilo

Siswadi

Subchan

Sugi Guritman

Suhartono

Tulus
Universitas Indonesia

Institut Pertanian Bogor

Institut Pertanian Bogor

Institut Pertanian Bogor

Universitas Indonesia

Institut Pertanian Bogor

Universitas Sumatera Utara

Institut Pertanian Bogor

Institut Teknologi Sepuluh Nopember

Institut Pertanian Bogor

Institut Teknologi Sepuluh Nopember

Universitas Sumatera Utara

Department of Matematics

FMIPA - Institut Pertanian Bogor

Jalan Meranti, Kampus IPB Dramaga Bogor

Phone/Fax: (0251) 8625276

Email: math@ipb.ac.id,jma.mathipb@gmail.com

Website: www.math.ipb.ac.id/ojs

$\mathfrak{J} \mathfrak{A} \mathfrak{A}\{$ is published twice in a year, in July and December. Editor receives original research papers and critical survey articles in all area of mathematics. In preparing the manuscript, please follow the author guideline (attached on the back cover). 


\section{GUIDELINES FOR AUTHORS}

$\mathfrak{J} \mathfrak{A} \mathfrak{A}$ is published twice in a year, in July and December and managed by Department of Mathematics, Institut Pertanian Bogor. Editor receives original research papers and critical survey articles in all area of mathematics. Article can be written in English or Indonesian. Article will be reviewed by editor using some criteria. Those are originality, significancy, technical strength, written presentation, and relevance to the journal. Author will be given for revising based on recommendation from reviewer/editorial boards. Manuscript could be submitted to:

\section{Department of Mathematics FMIPA - Institut Pertanian Bogor Jalan Meranti, Kampus IPB Dramaga Bogor \\ Phone/Fax: (0251) 8625276 \\ Email: math@ipb.ac.id, jma.mathipb@gmail.com}

Article is written using microsoft word, A4 paper, one column, Times New Roman font (14 size for title and 12 size for body text), single spacing. Upper/bottom/right margin is $3 \mathrm{~cm}$ and left margin is $4 \mathrm{~cm}$ (mirrored margin). No more than 20 pages.

Abstract is written in English or Indonesian, no more than 250 words. Keywords: 3-5 words.

Acknowledgment is written at the end of the paper before references.

References should be listed in alphabetical order according to the surnames of the authors at the end of the paper. The following reference style should be used:

[1] Brown RL. 1997. Introduction to the Mathematics of Demography. $3^{\text {rd }}$ Ed. Winsted: Actec Publications.

[2] Guritman S, Hooweg F, Simonis J. 2001. The Degree of Functions and Weights in Linear Codes. Discrete Applied Mathematics. 111(1): 87-102.

For specific details, please download $\mathfrak{I} \mathfrak{A t A}$ template in the website www.math.ipb.ac.id/ojs. 


\title{
$\mathfrak{I} \mathfrak{A} \mathfrak{A} \mathfrak{A}$
}

Journal of Mathematics and Its Applications

\author{
Vol. 14, No. 1, July 2015
}

Metode Steepest Descent dengan Ukuran Langkah Baru untuk Pengoptimuman Nirkendala

D. Wungguli, B. P. Silalahi, dan S. Guritman

Model Pendugaan Kerugian Akibat Bencana Letusan Gunung Api di Sektor Pertanian

L. D. Asih, H. Sumarno, dan P. Sianturi

Kajian Teoritik Kelas Kunci Lemah pada Kriptosistem Idea Berdasarkan Faktor Linear dan Kriptanalisis Diferensial

G. Taufik, S. Guritman, dan B. P. Silalahi

Dekoding Sindrom Kode Gilbert-Varshamov Biner Berjarak Minimum Rendah

A. Saepulrohman, S. Guritman, dan B. P. Silalahi

Penyelesaian Masalah Syarat Batas Persamaan Diferensial Biasa dalam Scilab dengan Menggunakan BVODE

A. D. Garnadi, F. Ayatullah, D. Ekastrya, S. Nurdiati, M. T. Julianto, dan

W. Erliana

Perilaku Dinamis Model Mangsa-Pemangsa Tipe Gause yang Diperumum dengan Waktu Tunda Pemanenan Konstan

Hasannudin, A. Kusnanto, dan Jaharuddin 